\title{
Analysis of factors affecting the financing with Islamic banks in agriculture sectors
}

\author{
Heri Sudarsono*, Mustika Noor Mifrahi, Indah Susantun, Ari \\ Rudatin, Sarastri Mumpumi Ruchba \\ Department of Economics, Faculty of Business and Economics, Universitas \\ Islam Indonesia Yogyakarta, Yogyakarta, Indonesia \\ *Corresponding author: heri.sudarsono@uii.ac.id
}

\author{
Article History \\ Received, 4 Agust 2019 \\ Revised 1, 11 September 2019 \\ Revised 2, 7 October 2019 \\ Accepted, 14 November 2019
}

\begin{abstract}
Purpose: This study aims to determine the effect of non-performing finance, inflation, interest rates, Bank Indonesia Sharia Certificate variable, deposit, and Industrial Production Index on the financing of the agricultural sector in Islamic banks.
\end{abstract}

Methodology: This study uses analysis tools with the Vector Auto Regression (VAR) method. The VAR method is applied if the data used is stationary and there is no cointegration. If the data used is stationary but there is cointegration, the analytical tool that will be applied is the Vector Correction Model (VECM) method.

Findings: There is a causality between interest rates and financing in the agricultural sector. This situation can be interpreted that any increase in interest rates will result in people preferring financing to Islamic banks. Profit sharing and margins do not directly influence the increase in interest rates in conventional banks so that the increase in interest rates is relatively a cheaper cost of financing. Conversely, if there is a decrease in the interest rate on conventional banks, it will make people more likely to choose the financing in conventional banks rather than in Islamic banks

Originality: This study enriches the discussion in factors affecting financing with Islamic Banks in agriculture sectors.

Keywords: Non-performing finance, Inflation, Bank Indonesia sharia certificate, Industrial Production Index, Financing of the agricultural sector

Cite this:

Sudarsono et al. (2019). Analysis of factor affecting financing with Islamic banks in agriculture sectors. Asian Journal of Islamic Management, 1(1), 80-100. DOI: 10.1108/AJIM.vol1.iss2.art6

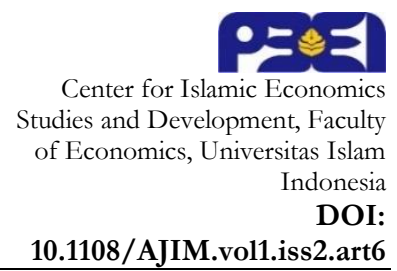

\section{Introduction}

Agricultural development is a process of social change aimed at improving the status and welfare of farmers. As well as developing the potential of farmers in the economic, social, political, cultural, environmental sectors through improving improvements, growth, and change (Ashari, 2009). The challenges faced by farmers in trying to optimize the agricultural sector are industrialization that is not based on agriculture. This situation causes the growth rate of the agricultural sector is lower than the rate of the industrial sector (Nasution, 2016).

The slowdown in the growth of the agricultural sector is also due to the narrowing of agricultural land. Based on a report from the Central Statistics Agency (BPS), he continued, there 
was a decline in the area of paddy raw land and in 2018 the area was only 7.1 million hectares. Previously in 2017, the area of paddy fields was at 7.75 million hectares and 8.12 million hectares in 2013. In addition, there was a decrease in the amount of labor absorption in the agricultural sector of 3.52 million people. In 2016, the number of workers employed in the agricultural sector was 39.22 million people, compared to 2018 of only 35.70 million people. Even in terms of income, the average wage in the agricultural sector still has a value of wages below the average national wage in 2018, which is Rp1, 76 million.

In addition, the difficulty and low funding in the agricultural sector is the reason farmers tend to switch to other sectors. One of the main problems in the development of the agricultural sector is the lack of capital support (Hassan et al., 2012). In this case, the government has tried to overcome it by launching a financing program for the agricultural sector (Aziz \& Yusoff, 2013). However, many of these funding programs are still using the interest-based system, so that it has an adverse effect on farmers. Sharia financing schemes will facilitate and ease farmers to develop the agricultural sector (Kocturk, Tepeci, Duramaz, \& Yatbaz, 2013).

Financing schemes with the principle of profit-sharing have opportunities in increasing the growth in the agricultural sector (Khasanah, Salim, Triyuwono, \& Irianto, 2013). The problem of financing in the agricultural sector is not only in Indonesia but also in several developing countries (Mohammed, Ahmed Ibrahim; Ogunbado, Ahamad Faosiy; Bashir, 2016). The character of the agricultural sector which tends to depend on the season and small income raises the risk of problematic financing is quite high (Tsabita, 2013). Regulation of Bank Indonesia (PBI) Number 3/1/2011 sets the level of risk as a bank health rating making Islamic banks less interested in entering the agricultural sector (Sutawi, 2008).

Table 1 shows that among 12 financing sectors in Islamic banks, the agricultural sector ranked 7 th after the wholesale and retail trade sectors, financial intermediaries, manufacturing, construction, real estate and electricity, as well as gas and water. The value of financing in 2014 was IDR 4.965 billion and in 2018 it rose to IDR 11, 497 billion or 56.81\%. Low financing in the financing sector shows that banks are trying to reduce the risk of financing incurred in this sector. Financing product schemes in Islamic banking are often considered to be inadequate to meet farmers' needs even though financing in the agricultural sector is quite potential (Farma, 2018).

Table 1. Financing of Full-Fledged Islamic Bank and Islamic Rural Bank for Business (Billion Rupiah)

\begin{tabular}{lrrrrr}
\hline Financing Sector & 2014 & 2015 & 2016 & 2017 & 2018 \\
\hline Agriculture, Hunting, and Forestry & 4.965 & 7.950 & 8.531 & 10.419 & 11.497 \\
Fishery & 714 & 1.198 & 1.405 & 1.462 & 1.204 \\
Mining and Excavation & 4.597 & 6.145 & 6.604 & 6.864 & 5.410 \\
Processing Industry & 13.300 & 17.982 & 19.745 & 21.463 & 24.363 \\
Electricity, Gas, and Water & 5.492 & 6.427 & 8.117 & 11.044 & 16.600 \\
Construction & 11.669 & 11.193 & 14.435 & 22.198 & 24.648 \\
Wholesale and Retail & 22.732 & 25.993 & 30.319 & 32.839 & 33.166 \\
Provider of accommodation, food, and drink & 1.555 & 2.101 & 3.043 & 3.613 & 4.728 \\
Transportation, warehouse, and communication & 12.192 & 11.072 & 10.921 & 10.087 & 9.374 \\
Financial Intermediary & 16.828 & 19.184 & 18.948 & 19.583 & 19.569 \\
Real Estate, Rental Business, and Corporate Services & 7.643 & 9.365 & 12.797 & 12.326 & 13.315 \\
Administration of Government Ruling, Defense, and & 85 & 266 & 9 & 7 & 4 \\
$\quad$ Mandatory Social Security & & & & &
\end{tabular}

Source: OJK, 2019

One of the main problems in the development of the agricultural sector is the lack of capital support (Hassan et al., 2012). In this case, the government has tried to overcome it by launching a financing program for the agricultural sector (Aziz \& Yusoff, 2013). However, many of these funding programs still use the interest system causing farmers to be burdened. 
Therefore, alternative financing schemes that are in line with farmers' problems are needed. Islamic banking can provide alternative financing models to support the development of the agricultural sector (Kocturk et al., 2013). Unlike conventional banking, Islamic banking uses the principle of profit sharing which is free from the interest system (Khasanah et al., 2013).

Shafiani (2015) found that the financing of the agricultural sector with profit-loss sharing schemes on al-muzara'ab and al-musaqa contract was able to improve the welfare of the people in Malaysia (Hi, Shafiai, \& Moi, 2017). Meanwhile, in the study of Sardar, et al (2013), it was found that Islamic banking is able to increase agricultural productivity because small farmers are able to benefit from Islamic bank financing products (Sardar, Azeem, Hassan, \& Bakhsh, 2013)

Meanwhile, Beik and Aprianti (2013) found that the bonus of Bank Indonesia Sharia Certificate (SBIS), interest on Bank Indonesia Certificate (SBI), equivalent rate of sharia financing and equivalent rate of third party funds had a positive effect on the level of agricultural financing. While the amount of third party funds and conventional bank interest rates negatively affect the level of agricultural financing. Meanwhile, in short and long term, the inflation rate and NonPerforming Financing (NPF) have no effect on the amount of agricultural finance (Beik, I.S, Aprianti, W, 2013)

Relating to the NPF relationship with agricultural finance, it is analyzed by analyzing variable responses through transmission tests. When an increase in the ratio of bad financing (NPF), it tends to reduce the financing channeled by Islamic banking, especially for the agricultural sector (Mughits \& Wulandari, 2016). This research is relevant to Maulida and Greece (2017) where NPF in the agricultural sector has a negative effect on the profitability of Islamic banking (Maulida \& Greece, 2017). Likewise in the study of Maulana and Iskandar (2018) found that the NPF level had a negative effect on the level of financing in the agricultural sector (Maulana \& Iskandar, 2018).

Saragih (2017) found many Islamic bank products that can be offered to the agricultural sector such as mudharaba, musharaka, muzara'ah, musaqoh, bai 'murabahah, bai istishna, bai' as-salam and rabn. But the development of Islamic banks is still not significant in the distribution of financing in the agricultural sector. This is due to inability of bank management to properly socialize agricultural financing products to farmers (Saragih, 2017).

\section{Research Method}

In this study, the data analysis method used is quantitative and descriptive method. This study uses analysis tools with the Vector Auto Regression (VAR) method. The VAR method is applied if the data used is stationary and there is no cointegration. If the data used is stationary but there is cointegration, the analytical tool that will be applied is the Vector Correction Model (VECM) method. There are several stages or pre-estimation tests that will be used before using the VAR analysis method, which are data stationarity test, VAR stability test, and determination of optimum lag length.

Unit root test is the most popular test to find out the stationary of a data. Then, to test the unit root, this study uses the Augmented Dickey-Fuller (ADF) test developed by Dickey and Fuller. It compares the ADF value with the critical value of Mac Kinnon 1\%, 5\%, and 10\%. In the ADF test, if the ADF value is smaller than the critical value of Mac Kinnon, it can be concluded that the data is stationary. If the data based on the ADF test is not stationary then the solution is to do difference non stationary processes. Stationary series results will lead to the use of VAR with standard methods. Meanwhile, non-stationary series will have implications for the use of VAR in the form of difference or VECM. The presence of non-stationary variables increases the likelihood of cointegration relationships between variables.

Var stability test is performed so that the resulting impulse response function (IRF) and Forecast Error Variance Decomposition (FEVD) are considered valid. VAR stability test is done by calculating the roots of polynomial functions or known as the roots of polynomial 
characteristic. If all the roots of the polynomial function are inside the unit circle or if the modulus is less than 1 , the VAR model is considered stable.

Cointegration is a long-term relationship between variables which although individually are not stationary, but the linear combination between variables can be stationary. Cointegration test aims to determine whether the variables are not stationary cointegrated or not. Two variables are not stationary before differentiation but stationary at first difference so that there is a great possibility that cointegration will occur, meaning that there is a long-term relationship between the two.

Determination of the optimal interval length can be identified using Akaike Info Criterion (AIC), Schwarz Info Criterion (SC), and Hannan Quinn Criterion (HQ). In this study, one of the methods above will be used through the criteria established by each method. The slowness of variables is needed to capture the effect of these variables on other variables in the model. Testing the optimal lap length is very useful to eliminate the autocorrelation problem in the VAR system, so that by using the optimal lag it is hoped that the autocorrelation problem does not arise.

Granger Causality Test is performed to see the causality relationship between the variables in the model. This is done because in reality the behavior of economic variables does not only have a one-way relationship but also shows a two-way relationship known as the concept of causality.

Impulse Response Function (IRF) is a method used to determine the response of endogenous variables to a particular variable shock. IRF analysis aims to find out how long it takes for a variable to respond to changes in other variables. A shock from an endogenous variable directly affects the variable itself and is also passed on to all other endogenous variables through dynamic structures in the VECM model. IRF measures the effect of a shock at a time on the innovation of endogenous variables at that time and in the future.

Forecast Error Variance Decomposition (FEVD) is a method to see the strengths and weaknesses of each variable that affects other variables over a long period of time. FEVD aims to predict the contribution of the percentage of variance for each variable due to changes in certain variables in the VAR system). So through FEVD can be known for certain factors that affect the fluctuations of certain variables.

\section{Result and Discussion}

\section{Result of Data Stationarity Test}

In this study, the data stationarity test uses the ADF test. The test is carried out at the level up to the first difference level by using the assumption of the Schwarz Info Criterion (SC) in the automatic lag length selection with a maximum lag value of 10 .

Table 2. Result of Data Stationarity Test on Level and First Difference

\begin{tabular}{lcccc}
\hline \multirow{2}{*}{ Variable } & \multicolumn{2}{c}{ Level } & \multicolumn{2}{c}{ First Difference } \\
\cline { 2 - 5 } & t-statistics & Probability & t-statistics & Probability \\
\hline PP & -2.499299 & 0.1221 & -5.386426 & 0.0000 \\
NPFPP & -1.159872 & 0.6840 & -6.756153 & 0.0000 \\
RATEPP & -2.181261 & 0.2156 & -10.62074 & 0.0000 \\
INFL & -1.831115 & 0.3613 & -5.564679 & 0.0000 \\
INTEREST & -15.78236 & 0.0000 & -26.58558 & 0.0001 \\
DPK & -0.039906 & 0.9497 & -8.001275 & 0.0000 \\
FDR & -0.365349 & 0.9064 & -9.183285 & 0.0000 \\
SBIS & -1.531376 & 0.5092 & -5.377629 & 0.0000 \\
IPI & 0.304309 & 0.9760 & -8.024149 & 0.0000 \\
\hline
\end{tabular}


In Table 2 the stationary test results show that the stationary variable at the level of INTEREST is indicated by a $5 \%$ verification level. Then, the stationary test at the first difference level shows that all variables are stationary. If the stationary data is fulfilled, the next step is to do the cointegration test. If cointegration occurs, the Vector Error Correction Model (VECM) will be used, but if cointegration does not occur then the first difference VAR model is used.

\section{Result of Optimum Lag Test}

Determination of the optimal amount of lag is a step that is needed in using VAR. The optimum lag test is used to find out how long a variable affects the other variables in an equation. AIC value with LR, FPE and HQ shows the smallest value in lag three. Thus, the lag value that will be used in the model as the optimum lag is lag three. This indicates that the current events were affected by the events of the previous three months.

Table 3. Result of Optimum Lag Test

\begin{tabular}{llllll}
\hline Lag & LogL & LR & FPE & AIC & HQ \\
\hline 0 & -101.2985 & NA & $1.78 \mathrm{e}-08$ & 4.857713 & 4.977447 \\
1 & 145.2003 & 394.3982 & $5.58 \mathrm{e}-12$ & -3.253347 & -2.175738 \\
2 & 234.7550 & 111.4458 & $2.35 \mathrm{e}-12$ & -4.389109 & -2.353626 \\
3 & 336.0115 & $90.00582^{*}$ & $1.02 \mathrm{e}-12^{*}$ & $-6.044956^{*}$ & $-3.051598^{*}$ \\
\hline
\end{tabular}

\section{Result of VAR Stability Test}

The VAR Stability Test calculates the roots of polynomial functions which are performed to obtain valid values and results on the Impulse Response Function and Forecast Error Variance Decomposition. If the absolute modulus value is less than one then the VAR model is considered stable. The modulus values shown in table 4 is the model range between $0.215064-0.968098$. Based on these results, it can be concluded that the VAR model is stable at length, thus the FEDV test can be performed on this model which produces a valid output.

Table 4. Result of VAR Stability Test

\begin{tabular}{ll}
\hline \multicolumn{1}{c}{ Root } & Modulus \\
\hline 0.968098 & 0.968098 \\
$0.857463-0.149059 \mathrm{i}$ & 0.870323 \\
$0.857463+0.149059 \mathrm{i}$ & 0.870323 \\
$-0.627988-0.373410 \mathrm{i}$ & 0.730619 \\
$-0.627988+0.373410 \mathrm{i}$ & 0.730619 \\
$0.695454-0.177692 \mathrm{i}$ & 0.717796 \\
$0.695454+0.177692 \mathrm{i}$ & 0.717796 \\
$0.143361-0.647556 \mathrm{i}$ & 0.663236 \\
$0.143361+0.647556 \mathrm{i}$ & 0.663236 \\
$0.098982-0.554773 \mathrm{i}$ & 0.563534 \\
$0.098982+0.554773 \mathrm{i}$ & 0.563534 \\
$0.440010-0.341034 \mathrm{i}$ & 0.556698 \\
$0.440010+0.341034 \mathrm{i}$ & 0.556698 \\
$-0.116454-0.280714 \mathrm{i}$ & 0.303911 \\
$-0.116454+0.280714 \mathrm{i}$ & 0.303911 \\
-0.215064 & 0.215064 \\
\hline
\end{tabular}

\section{Result of Cointegration Test}

Cointegration testing in this study was carried out using the Johanssen's Trace Statistics or Johanssen Cointegration Test which aims to determine whether non-stationary variables have cointegration or not. Cointegration test also aims to find out how many equations in a 
cointegrated system if the cointegration test results of the trace statistic value are greater than the critical value of $5 \%$.

Table 5. Result of Cointegration Test

\begin{tabular}{lcccc}
\hline $\begin{array}{c}\text { Hypothesized } \\
\text { No. of CE(s) }\end{array}$ & Eigenvalue & Trace Statistic & $\begin{array}{c}0.05 \mathrm{~b} \text { Critical } \\
\text { Value }\end{array}$ & Prob.** \\
\hline None ${ }^{*}$ & 0.974108 & 454.1874 & 159.5297 & 0.0000 \\
At most $1 *$ & 0.877105 & 293.4193 & 125.6154 & 0.0000 \\
At most 2 & 0.787704 & 201.1766 & 95.75366 & 0.0000 \\
At most 3 & 0.722244 & 132.9864 & 69.81889 & 0.0000 \\
At most 4 & 0.519608 & 76.62196 & 47.85613 & 0.0000 \\
At most 5 & 0.421118 & 44.36320 & 29.79707 & 0.0006 \\
At most 6 & 0.335595 & 20.31028 & 15.49471 & 0.0087 \\
At most 7 & 0.051367 & 2.320258 & 3.841466 & 0.1277 \\
\hline
\end{tabular}

Based on the results of the Johannsen Cointegration Test in Table 5, the model used in this study has six cointegration equations. This cointegration equation shows that among the variables tested have a cointegration linear combination relationship so that the VECM model can be done in this study.

\section{Result of VECM Estimation}

The long term VECM estimation results show that all variables affect the level of financing in the agricultural sector. The average margin level of agricultural sector financing (RATEP) has a positive and significant effect on the ratio of agricultural sector financing in the long run with a coefficient value of 0.096588 , when the RATEP variable increases by $1 \%$, it will cause an increase in the ratio of agricultural sector financing by $0.896182 \%$. This shows that the average level of financing margin in the financing sector follows the level of financing issued by Islamic banks. The average margin level of return is the value of the income received from the level of financing provided by bank management.

Table 6. Result of Long-Term Estimation

\begin{tabular}{lrr}
\hline \multicolumn{1}{c}{ Variable } & Coeficient & t-Statistics \\
\hline RATEP(-1) & 0.096588 & $7.64076^{*}$ \\
LOG(NPFP(-1)) & -0.285454 & $-4.15104^{*}$ \\
INFLASI(-1) & 0.034652 & $5.27478^{*}$ \\
BUNGAP(-1) & -0.344600 & $-5.19537^{*}$ \\
SBIS(-1) & -0.068698 & $-12.2605^{*}$ \\
LOG(DPK(-1)) & -0.372672 & $-2.07558^{*}$ \\
IPI(-1) & -0.025613 & $-13.2338^{*}$ \\
C & 7.907684 & \\
\hline
\end{tabular}

The NPF variable in agricultural financing has a negative and significant effect on the level of financing for the agricultural sector in the long run with a coefficient value of 0.285454 . This situation shows that when there is an increase in NPF of $1 \%$ will reduce the financing of the agricultural sector by $0.28 \%$. This situation shows that bank management is able to minimize the risk of financing through policies issued. Efforts to reduce the financing risks can cause the financing problem through the tightening of doubtful debt. The success of many management in disbursing problematic financing is shown by the decline in the ratio of agricultural NPF to the value of financing in the agricultural sector, in 2015 was R 54.1\%, whereas in 2016, 2017 and 2018 respectively $4.45 \%, 3.09 \%$ and $2,45 \%$. 
Inflation variable has a positive effect on the ratio of financing the agricultural industry sector in the long run with a coefficient value of 0.137719 . This situation shows that when there is an increase in inflation by $1 \%$ will increase the financing ratio of the manufacturing sector by $0.137719 \%$. The level of inflation becomes a consideration of bank management in determining the amount of financing in the agricultural sector. The level of inflation will reduce the value of financing issued by banks because production costs tend to be expensive. However, the agricultural sector is a given sector, so that it has an inelastic relationship with the inflation rate. Output of agriculture sector is largely the basic needs of the people who are not much affected by declining purchasing power.

Interest rate variable has a negative effect on the ratio of agricultural sector financing in the long run with a coefficient of -0.344600 . This shows that when the variable interest rate increases by $1 \%$ it will cause an increase in the ratio of financing the manufacturing sector by $0.578567 \%$. Interest rates affect the management of Islamic banks in making financing policies in the agricultural sector. Even though Islamic banking does not use the interest system in the fund management system, interest is often a reference for Islamic banks in dealing with liquidity. If so the increase in the interest rate will reduce financing in the real sector

Bank Indonesia Sharia Certificate variable (BSBIS) has a significant negative effect on financing the manufacturing sector in the long run with a coefficient of -0.068698 . This means that every $1 \%$ increase in BSBIS will cause a decrease in the processing industry sector financing ratio of $-0.068698 \%$. This happens because the SBI interest rate affects the interest rate of commercial banks, changes in interest rates will affect the margin level and profit sharing ratio. Increased margins and ratios will reduce investment in the defense sector

Table 7. Result of Long-Term Estimation

\begin{tabular}{lcc}
\hline \multicolumn{1}{c}{ Variable } & Coefficient & t-Statistics \\
\hline CointEq1 & -0.468405 & $-3.49879^{*}$ \\
D(LOG(AGRICULT(-1))) & 0.111645 & 0.69870 \\
D(LOG(AGRICULT(-2))) & -0.017418 & -0.10025 \\
D(LOG(AGRICULT(-3))) & 0.362799 & 1.81187 \\
D(RATEP(-1)) & 0.070091 & $3.36092^{*}$ \\
D(RATEP(-2)) & -0.023632 & -1.03285 \\
D(RATEP(-3)) & 0.011304 & 0.74681 \\
D(LOG(NPFP(-1))) & -0.296704 & $-3.02130^{*}$ \\
D(LOG(NPFP(-2))) & -0.101574 & -1.18316 \\
D(LOG(NPFP(-3))) & 0.057682 & 0.59470 \\
D(INFLATION(-1)) & 0.010102 & 0.72802 \\
D(INFLATION(-2)) & -0.010141 & -0.55758 \\
D(INFLATION(-3)) & -0.030697 & $-2.30502^{*}$ \\
D(INTEREST(-1)) & -0.140891 & -1.53750 \\
D(INTEREST(-2)) & 0.048964 & 0.37704 \\
D(INTEREST(-3)) & 0.513027 & $3.77780^{*}$ \\
D(SBIS(-1)) & -0.010096 & -1.12170 \\
D(SBIS(-2)) & 0.007087 & 0.72043 \\
D(SBIS(-3)) & -0.011855 & -1.25381 \\
D(LOG(DPK(-1))) & 0.254571 & 0.70290 \\
D(LOG(DPK(-2))) & -0.999441 & $-3.22331^{*}$ \\
D(LOG(DPK(-3))) & -0.862347 & $-2.91657^{*}$ \\
D(IPI(-1)) & -0.012716 & $-3.17079 *$ \\
D(IPI(-2)) & -0.007368 & $-2.14183^{*}$ \\
D(IPI(-3)) & -0.003514 & -1.55410 \\
C & 0.056924 & $2.69425^{*}$ \\
\hline
\end{tabular}


Deposits variable negatively affects long-term agricultural sector financing with a coefficient of -0.372672 . This means that every $1 \%$ increase in deposits will increase the financing of the manufacturing sector by $0.372672 \%$ assuming ceteris paribus. DPK is one of the largest sources of funding for Islamic banks, which comes from savings, time deposits and current accounts. The higher DPK obtained, the bank has the opportunity to allocate funds in various forms of financing. During 2015-2018, the total DPK was IDR 174,895, IDR 206,407, IDR 238, 393 and IDR 257,606 billion, respectively. Where the ratio of agricultural financing to third deposits in 2015 was $4.54 \%$ and in 2018 it fell to $4.46 \%$. This shows that the management of Islamic banks is more allocating financing to the non-agricultural sector, such as the wholesale and retail trade sector, financial intermediaries, manufacturing, construction, real estate and electricity, gas and water.

The IPI variable has a significant negative effect on the financing ratio of the manufacturing sector in the long run with a coefficient value of 0.000387 . This means that every $1 \%$ increase in the Industrial Production Index will increase the financing of the manufacturing sector by $0,000387 \%$ assuming ceteris paribus. This situation is caused when the economy is in good condition it will support the implementation of Islamic banking activities that prioritize the distribution of funds in the real sector, including financing to the agricultural sector. When IPI increases, the overall financing increases but financing in the agricultural sector tends to fall. IPI encourages entrepreneurs in the wholesale and retail trade sector, financial intermediaries, manufacturing, construction, real estate and electricity, gas and water. The financing sector in the agricultural sector is more influenced by external factors such as seasons, rice seeds, medicines and fertilizers so that they cannot be able to produce at any time.

Based on the results presented in Table 7, the VECM estimation results show that there is a significant error correction of 0.468405 , this is the coefficient of speed of adjustment to equilibrium which means that each month the error is corrected by $4.68405 \%$ towards the optimal target of financing. There are ten significant variables at the real level of five percent plus one error correction of tenth variable. Significant variables at the five percent level are the average yield (RATEP) at lag 1, NPF at lag 1, inflation at lag 3, interest rate at lag 3, DPK at lag 2 and 3 and IPI at lag 1 and 2. The presumption of significant error correction parameters proves that there is an adjustment mechanism from the short run to the long run. The amount of adjustment from short-term to long-term is -0.46 percent.

\section{Result of Impulse Response Function (IRF) Analysis}

IRF is used to determine the response of an endogenous variable to a particular shock. This is because shock variables, for example I, do not only affect the $\mathrm{i}$-th variable, but are transmitted to all other variables through the lag structure in VECM. IRF does not describe the magnitude of the impact of a variable on other variables such as the VECM Estimation Test, but the IRF describes the form of the response of the dependent variable to the shock of an exogenous variable and the time required to return to the equilibrium point. This study examines the effect of shock over the next 60 periods.

This analysis will explain the effect and response of the financing of the manufacturing sector if there are shocks to the variables NPF, INFLATION, INTEREST, SBIS, DPK and IPI. Response of industry's financing ratios if shocks occur is shown in Figure 1.

From the whole analysis of the impulse response of the processing industry financing to shocks that occur in the variables used, it is seen that the financing of the agricultural industry reaches the fastest stability when shocks occur on the NPF variable. The study results show that the achievement of NPF stability obtained in the 23rd month is faster than other variables. This proves that shocks to NPF are easier to handle compared to shocks to other variables and it can be concluded that the category of banking performance has the most stable effect compared to other variables. 
Response to Cholesky One S.D. Innovations

Response of LOG(PERTANIAN) to LOG(PERTANIAN)

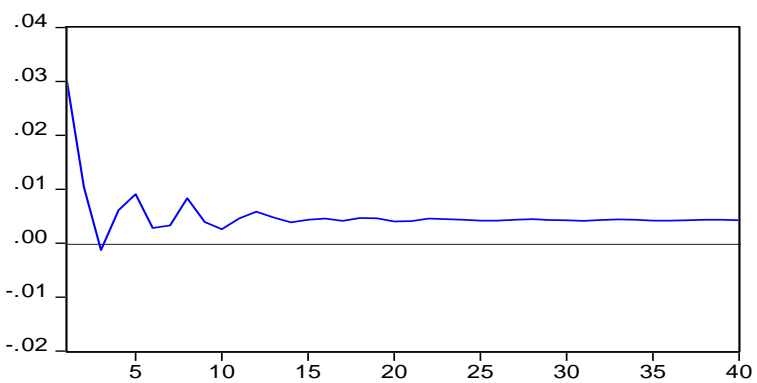

Response of LOG(PERTANIAN) to LOG(NPFP)

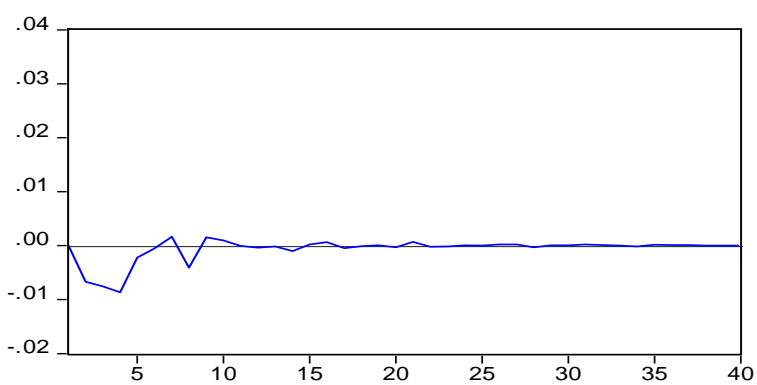

Response of LOG(PERTANIAN) to BUNGAP

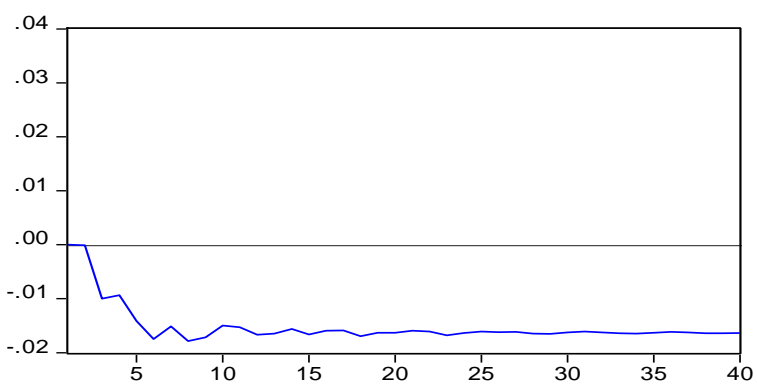

Response of LOG(PERTANIAN) to LOG(DPK)

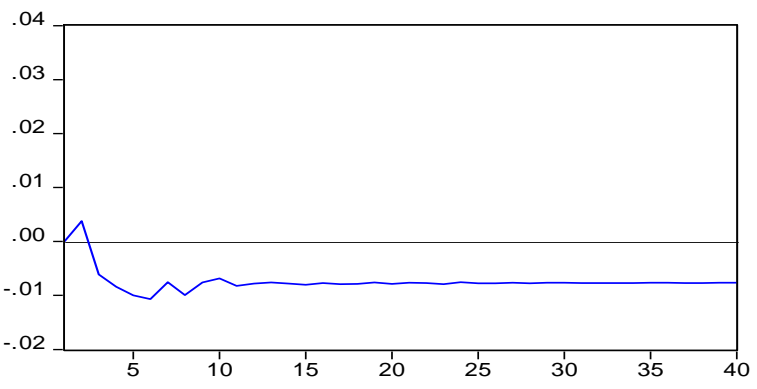

Response of LOG(PERTANIAN) to RATEP

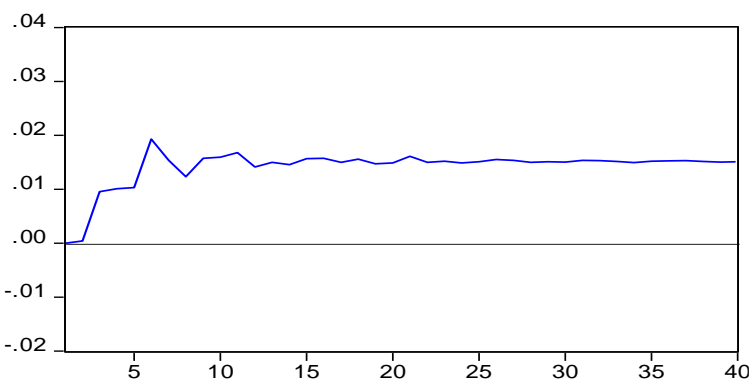

Response of LOG(PERTANIAN) to INFLASI

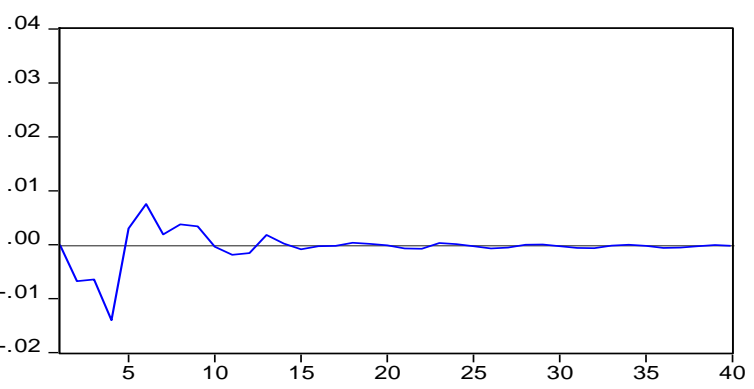

Response of LOG(PERTANIAN) to SBIS
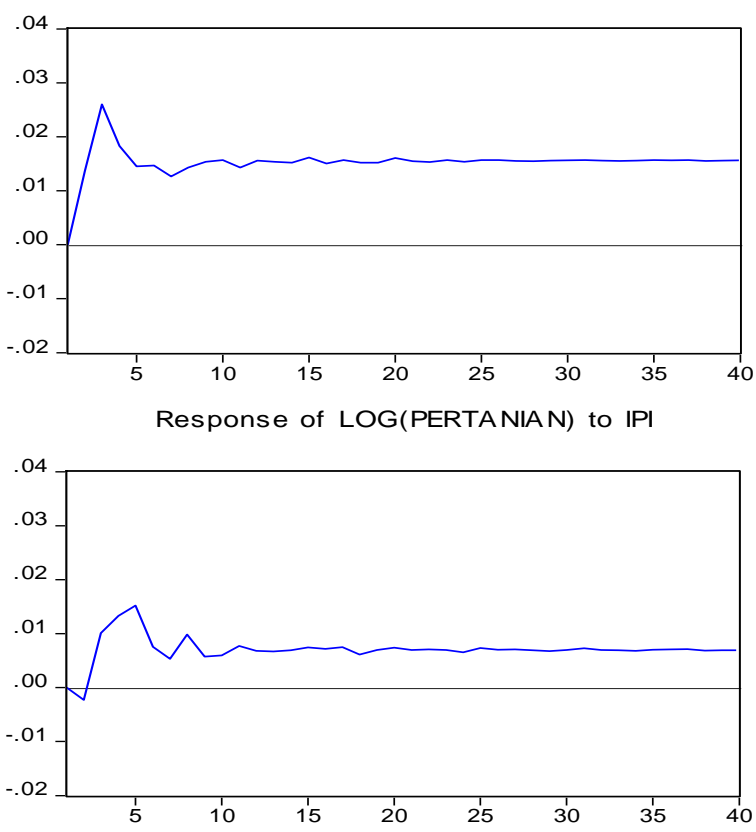

Figure 1. Response to Cholesky One S.D. Innovations

\section{Conclusion}

Based on research that has been done, it can be concluded that there is causality between interest rates and financing in the agricultural sector. This situation can be interpreted that any increase in interest rates will result in people preferring financing to Islamic banks. Profit-sharing and margins do not directly influence the increase in interest rates in conventional banks. so that the increase in interest rates is relatively a cheaper cost of financing. Conversely, if there is a decrease in the interest rate on conventional banks, it will make people more likely to choose the financing in conventional banks rather than in Islamic banks.

In the long run, NPF, INFLATION RATE, INTEREST, SBIS, DPK and IPI have an effect on the financing of agricultural sector. Most variables do not meet the hypothesis of 
influencing the financing in the agricultural sector. This condition shows that the management of Islamic banks has not made agricultural financing as either a priority of funding or a source of bank income. Meanwhile, in the short term, there is a correction to the equation formed in this study.

\section{References}

Ashari. (2009). Peran perbankan nasional dalam pembiayaan sektor pertanian di Indonesia. Forum Penelitian Agro Ekonomi, 27(1), 13-27.

Aziz, M. R. ., \& Yusoff, M. . (2013). Financing for agro projects in Islamic banks. International Conference on Agriculture and Biotechnology IPCBEE, 60, 14-18. https://doi.org/10.7763/IPCBEE.

Beik, I.S, Aprianti, W, N. (2013). Analisis faktor-faktor yang mempengaruhi pembiayaan Bank Syariah untuk sektor pertanian di Indonesia. Jurnal Agro Ekonomi, 31(1), 19-36.

Farma, J. (2018). Prospek dan tantangan perbankan syariah dalam pembiayaan sektor pertanian. Pedadogik; Jurnal Ilmiah Pendidikan Dan Pembelajaran, 5(2), 52-67.

Hassan, M. T., Sattar, M. A., Tousif, M. A., Nasir, N., Sadiq, M., \& Yasmeen, M. (2012). Role of Islamic banking in agriculture development in Bahawalpur, Pakistan. International Journal of Learning \& Development, 2(3), 123-138. https://doi.org/10.5296/ijld.v2i3.1817

Hi, M., Shafiai, M., \& Moi, M. R. (2017). Financial problems among farmers in Malaysia: Islamic agricultural finance as a possible solution. Asian Social Science, 11(4), 1-16. https://doi.org/10.5539/ass.v11n4p1

Khasanah, U., Salim, U., Triyuwono, I., \& Irianto, G. (2013). The practice of profit and loss sharing system for rice farmers in East Java, Indonesia. IQSR Journal of Business and Management, 9(3), 1-7.

Kocturk, O. M., Tepeci, M., Duramaz, S., \& Yatbaz, A. (2013). The use of agricultural loan : An analysis of farmers' bank selection decisions in Manisa, Turkey. Journal of Food, Agriculture \& Environment, 11 (3 \& 4), 764-768.

Maulana, H., \& Iskandar, E. (2018). Analisis integrasi pembiayaan sektor pertanian dan nilai tukar petani di Indonesia. Jurnal Ekonomi Regional Unimal, 1(3), 38-49.

Maulida, S., \& Yunani, A. (2017). Masalah dan solusi model pengembangan pembiayaan pertanian dari aspek keuangan syari' ah. Cakrawala: Jurnal Studi Islam, 12(2), 91-100.

Mohammed, Ahmed Ibrahim; Ogunbado, Ahamad Faosiy; Bashir, A. (2016). The viablitilty of Salam finance in teh growth of agricultural Production in Kano State, Nigeri. Asian Journal of Multidiisciplinary Studies, 4(12), 87-92.

Mughits, M., \& Wulandari, R. (2016). Kontribusi pembiayaan bank syariah untuk sektor pertanian di Indonesia contribution of Islamic bank financing for agricultural sector in Indonesia. Jurnal Al Muzara'ah, 4(1), 61-75.

Nasution, Z. (2016). Model pembiayaan syariah untuk sektor pertanian. Iqtishadia, Jurnal Ekonomi Dan Perbankan Syariah, 3(2), 325-343.

Saragih, F. H. (2017). Pembiayaan syariah sektor pertanian. Agrica (Jurnal Agribisnis Sumatera Utara), 10(2), 112-118.

Sardar, A., Azeem, M. M., Hassan, S., \& Bakhsh, K. (2013). Comparison of efficiency between pure Islamic banks and Islamic bank windows and role of Islamic banking in agriculture sector. Pakistan Journal of Agricultural Science, 50(1), 155-161. 
Sutawi. (2008). Pembiayaan syariah pada usaha mikro, kecil dan menengah sektor agribisnis dengan pola kemitraan. Jurnal Kenangan Dan Perbankan, 12(3), 447-458.

Tsabita, K. (2013). Analisis risiko pembiayaan syariah pada sektor pertanian. Jurnal Al-Mu₹ara'ah, 2(2), 88-120. 